\title{
Biochemical characteristics of myofibrillar proteins of the fish parasite Isoparorchis hypselobagri (Trematoda) as survival traits in an oxygen-rich environment
}

\author{
USMA ABBASI, RIAZ AHMAD and ABSAR-UL HASNAIN \\ Laboratory of Biochemical Genetics, Section of Genetics, Department of Zoology, \\ Faculty of Life Sciences, Aligarh Muslim University, Aligarh-202 002 (U.P.), India \\ Corresponding author: Absar-ul Hasnain, absarhb@rediffmail.com
}

(Received on 2 April 2011; Accepted on 24 February 2012)

\begin{abstract}
We have investigated biochemical properties of myofibrillar proteins of the digenetic trematode Isoparorchis hypselobagri, which correlate with its survival in the oxygen-rich swim bladder of its host catfish (Wallago attu). The polypeptide composition of the trematode's natural actomyosin (NAM) was striated-muscle-like, with the exception that a $98-\mathrm{kD}$ polypeptide corresponding to paramyosin also existed in its sodium dodecyl sulfate polyacrylamide gel electrophoresis (SDS-PAGE) profiles. The profiles of immunoprecipitated NAM of the trematode support these inferences. $\mathrm{Ca}^{2+}$-sensitivity of myofibrillar contractility and $\mathrm{Mg}^{2+}$-ATPase activity of $I$. hypselobagri resembled troponin-linked calcium regulation of the host striated muscle. Myofibrillar permeability to water influx was insensitive to calcium chelation at neutral $\mathrm{pH}$. However, the host swim bladder myofibrils displayed smooth-muscle-like polypeptide composition, $\mathrm{pH}$ dependence of contractility, $\mathrm{Ca}^{2+}$-sensitivity, ATPase activities, and inactivation kinetics. We propose 2 survival strategies that $I$. hypselobagri appears to have co-evolved: $(i)$ fast-muscle-like musculature with exceptionally high contractility or ATPase activity; and (ii) type-II myosin resembling the host muscle in functional plasticity.
\end{abstract}

Keywords: Isoparorchis hypselobagri, immunoprecipitation, natural actomyosin, contractility, myofibrillar ATPase, oxygen-rich environment, Wallago attu

\section{INTRODUCTION}

Isoparorchis hypselobagri is a digenetic trematode that parasitizes Wallogo attu, a tropical catfish of wide distribution and commercial importance. The trematode completes its life cycle in 2 intermediate hosts, while $W$. attu is its definitive host. The parasite lives in the catfish swim bladder, which is an organ of relatively low contractility but high oxygen content (SIDDIQUI \& NIZAMI 1975). Therefore, beside the low contractility of the afflicted organ, which may restrict propagation of the parasite, the high oxygen content of the swim bladder is a major metabolic challenge for the survival of I. hypselobagri. 
Parasites have evolved a diverse array of adaptive strategies to survive within the host tissues/organs. The type of musculature is crucial for attachment of the parasite to the host, subsequent tissue invasion, motility within afflicted organs, and transmigration. Functional properties of a muscle type are essentially determined by characteristics of its constituent contractile proteins. Published evidence on human parasites implicates actomyosin motor and unique cytoskeleton protein complexes in motility at various stages of parasite life cycles (DoBrowOLSKI et al. 1997; PINDER et al. 1998; Pezzela-D’Alessandro et al. 2001; Heintzelman 2004; Soldatti-Favre 2008). Developmental stage-specific gene expression of various types of myosin (Gonzalez-Malerva et al. 2004; Cruz-Rivera et al. 2006; KAtTA et al. 2009) and actin, as well as the mechanisms of host invasion by actin-based motility, have already been identified (Field et al. 1993; Wetzel et al. 2003; Chaparro-Olaya et al. 2005; SChÜLER \& MAtuschewski 2006; SChMitz et al. 2010).

No data are available on myofibrillar proteins of fish parasites and their adaptability. However, the existence of a specific hemoglobin in I. hypselobagri (RASHID et al. 1997; KIGER et al. 1998) does suggest that this parasite has evolved strategies to deal with oxygen overload within the swim bladder of the host catfish. In order to identify functional traits of the trematode muscles, which are compatible with the metabolic demands, we have compared several functional characteristics of myofibrils of the trematode with those of the afflicted organ (swim bladder) and the host skeletal muscle. While the fish swim bladder is a smooth muscle organ, skeletal muscle is typically of the striated type. Sodium dodecyl sulfate polyacrylamide gel electrophoresis (SDS-PAGE) profiling of natural actomyosin (NAM) and immunocross-reactivity have been employed to infer muscle-type(s) of I. hypselobagri based on correspondence or differences with the polypeptide composition of the host swim bladder or skeletal muscle.

\section{MATERIALS AND METHODS}

\section{Sample preparation}

Wallago attu, captured from the Upper Ganges Canal $\left(30^{\circ} 24^{\prime} \mathrm{N}, 78^{\circ} 39^{\prime} \mathrm{E}\right.$, located $26 \mathrm{~km}$ from our research laboratory in Uttar Pradesh, India), were brought to the laboratory fresh and live. To prepare myofibrils and NAM, white dorsolateral muscle of the fish was used. Besides, the whole swim bladder was washed thoroughly with chilled isotonic saline and used to prepare myofibrils, and NAM was extracted from them. I. hypselobagri was collected by cutting open the swim bladders of W. attu and kept live in the isotonic saline for further processing. Myofibrils and NAM were prepared from whole parasites following the procedures described below.

\section{Preparation of myofibrils and NAM}

White dorsolateral muscle removed from the fish, its swim bladders or the trematode, was minced and the pellets of either type were washed 3 times with $1 \%$ Triton-X100 to remove contamination of subcellular organelles prior to suspension in $\mathrm{KCl}$-rich buffer. To obtain myofibrils, the pellet of minced tissue was homogenized in chilled low-ionic-strength buffer by using a mechanical homogenizer (Biospec, USA, 
model 985-380) at $2000 \mathrm{rpm}$ and $4^{\circ} \mathrm{C}$ for $10 \mathrm{~min}$. The composition of the buffer was as follows: $25 \mathrm{mM} \mathrm{KCl}, 5 \mathrm{mM}$ ethylene diamine tetraacetic acid (EDTA), $25 \mathrm{mM}$ Na-borate (pH 7.1), and $0.5 \mathrm{mM}$ phenylmethylsulfonyl fluoride (PMSF). Myofibrils were harvested by centrifugation at $1000 \mathrm{~g}$. After 2 cycles of homogenization and washing with suspension buffer $(0.1 \mathrm{M} \mathrm{KCl}$ and $2 \mathrm{mM} \beta$-mercaptoethanol), myofibrils were finally suspended in the washing buffer. The quality of preparations was monitore by using SDS-PAGE and the integrity of myosin heavy chain (MyHC) as the index.

The procedure of NAM extraction from fish skeletal muscle was outlined previously (AHMAD \& HASNAIN 2006). A few modifications were applied to extract NAM from smooth muscle of the swim bladder and the whole parasite. Briefly: instead of the widely used source, i.e. minced tissue, the starting source were myofibrils, which were suspended in a buffer containing $0.6 \mathrm{M} \mathrm{KCl}, 5 \mathrm{mM}$ sodium pyrophosphate ( $\mathrm{pH} 8.0)$. After $3 \mathrm{~h}$ of gentle stirring, the contents were centrifuged at $5000 \mathrm{rpm}$ and $4^{\circ} \mathrm{C}$ for $10 \mathrm{~min}$. The resulting pellet was again suspended and constantly stirred for $3 \mathrm{~h}$ in $0.6 \mathrm{M} \mathrm{KCl}$. Following centrifugation, the 2 supernatants were pooled and precipitated by diluting $\mathrm{KCl}$ to $0.2 \mathrm{M}$. The precipitate was saved and dissolved in $0.6 \mathrm{M}$ $\mathrm{KCl}$ containing $0.025 \mathrm{M}$ Tris-maleate buffer $(\mathrm{pH} 7.0)$. Exhaustive dialysis against the same buffer followed. After final centrifugation at $8000 \mathrm{~g}$, the thick viscous supernatant was taken as NAM.

\section{Protein estimation}

Protein concentrations of myofibrils and NAM were estimated by the biuret method, as described by GorNALL et al. (1949). Bovine serum albumin (BSA) was used as the standard, and absorbance was recorded at $540 \mathrm{~nm}$.

\section{$S D S-P A G E$}

The electrophoresis was performed using slab gels of $100 \mathrm{~mm} \times 150 \mathrm{~mm} \times 1 \mathrm{~mm}$ of $10 \%$ polyacrylamide containing $1 \%$ SDS and $10 \%$ glycerol, as described previously (AHMAD \& HASNAIN 2006). Experiments were run at $10 \mathrm{~mA} / \mathrm{gel}$ until the tracking dye entered the separating gel, and next the current was raised to $25 \mathrm{~mA} / \mathrm{gel}$, maintained throughout the electrophoresis. To visualize protein bands, the gel was stained with Coomassie brilliant blue (CBB) or silver stain (OAKLEY et al. 1980).

\section{Molecular weight estimation}

Molecular weights $\left(M_{r}\right)$ of polypeptides in SDS-PAGE profiles were analyzed by GelPro software (Cybernetics, USA, 1995). To estimate $M_{r}$ or to quantify protein in individual bands, densitometry of photo prints or gel scans was performed using Scion-Image software system (Beta release 4.0). Chicken actomyosin was used as the standard molecular weight marker.

\section{Preparation of antisera and immunoprecipitation}

Antisera were raised in white Swiss rabbit by using NAM of $W$. attu skeletal muscle as an antigen. For immunization, host muscle NAM preparations $(\sim 0.5 \mathrm{mg})$ 
were emulsified with Freund's complete adjuvant. On a weekly basis, intramuscular injections of the emulsion were given to the animal. At the end of the third week, the rabbit was bled from the marginal ear-vein. Sera were obtained by low-speed centrifugation, after removing the clot. The antiserum was de-complemented by incubation at $56^{\circ} \mathrm{C}$ for $30 \mathrm{~min}$, followed by centrifugation at $15000 \mathrm{~g}$ for $15 \mathrm{~min}$.

To immunoprecipitate a tested NAM, $\sim 200 \mu \mathrm{g}$ of $W$. attu skeletal muscle or swim bladder or of the parasite was taken and mixed with antisera (containing the primary antibody). The mixture was incubated with gentle mixing overnight at $4^{\circ} \mathrm{C}$. Next morning, the contents were mixed with bead slurry (Protein A/G agarose) in $30-50 \mu \mathrm{l} / \mathrm{bed}$ volume. The mixture was incubated with gentle agitation for $2-3 \mathrm{~h}$ at $4^{\circ} \mathrm{C}$. The immunoprecipitated complex was collected in a pellet by centrifugation $3000 \mathrm{~g}$ for $1 \mathrm{~min}$ at $4^{\circ} \mathrm{C}$. The pellet was washed several times with $1 \mathrm{X}$ washing buffer at $3000 \mathrm{~g}$ and $4^{\circ} \mathrm{C}$. The pellet was re-suspended in 25-100 $\mu$ l of Laemmli's sample buffer to a final concentration of $1 \mathrm{X}$ sample buffer. Samples were incubated at $95^{\circ} \mathrm{C}$ for $5 \mathrm{~min}$ and screened on 10\% SDS-PAGE. Corresponding controls were also run.

\section{pH dependence of the effect of calcium on water retention by myofibrils}

Myofibrils were initially discriminated by water influx or swelling effect at various $\mathrm{pH}$ values. Following suspension in buffers of various $\mathrm{pH}$, myofibrils $(5 \mathrm{ml})$ were packed by centrifugation at a low speed $(1000 \mathrm{~g})$ at $20^{\circ} \mathrm{C}$ for $5 \mathrm{~min}$. The volume of supernatant was measured with the help of a micro-syringe and deducted from the original volume $(5 \mathrm{ml})$ to obtain the volume of the packed myofibrils. The packedvolume fraction was converted into percentage (\%) and plotted against $\mathrm{pH}$ values. To monitor if calcium affects the influx, experiments were repeated in the presence of $0.001 \mathrm{mM} \mathrm{CaCl}_{2}$.

\section{ATPase assays and thermal inactivation}

$\mathrm{Mg}^{2+}$-ATPase activity was assayed in a reaction mixture that at the final concentration contained: $50 \mathrm{mM} \mathrm{KCl}, 5 \mathrm{mM} \mathrm{MgCl}, 1 \mathrm{mM}$ ATP, $25 \mathrm{mM}$ Tris-maleate ( $\mathrm{pH} 7.0$ ) or Tris-HCl buffer ( $\mathrm{pH} 7.5)$, and $2.5-3.0 \mathrm{mg} \mathrm{ml}^{-1}$ of NAM or myofibrils. However, to bring assay conditions close to physiological ambience, the reaction mixture also contained $0.001 \mathrm{mM}$ calcium. To chelate $\mathrm{Ca}^{2+}, 1 \mathrm{mM}$ ethylene glycol tetraacetic acid (EGTA) was mixed to myofibrils prior to assay. Figure legends show if the variable in ATPase assay was the salt concentration or the $\mathrm{pH}$.

To assay $\mathrm{Ca}^{2+}$-ATPase activity, $\mathrm{CaCl}_{2}$ was substituted for $5 \mathrm{mM} \mathrm{MgCl}_{2}$. Other components of the assay mixture were of the same molarity and $\mathrm{pH}$ as used for $\mathrm{Mg}^{2+}$-ATPase. Experiments were performed at $20^{\circ} \mathrm{C}$ and the liberated inorganic phosphate $(\mathrm{P} i$ ) was estimated as described previously (AHMAD \& HASNAIN 2006). All of the measurements were made at $640 \mathrm{~nm}$ on GENESYS-10 UV-Visible Spectrophotometer.

For thermal inactivation of ATPase, each NAM was incubated at $45^{\circ} \mathrm{C}$ for 20 min. Aliquots pipetted out at 5-min intervals were chilled in crushed ice. After 5 min, $\mathrm{Ca}^{2+}$-ATPase was assayed according to the protocol given above. 


\section{Measurements of the contractility}

The contractility of each type of myofibrils was estimated by a simple protocol described by SAKAмото \& ARAi (1979). Myofibrils of the control (packed volume $\left.\mathrm{Pv}_{\mathrm{o}}\right)$ or the aliquot after adding $\mathrm{Mg}^{2+}-\mathrm{ATP}\left(\mathrm{Pv}_{\mathrm{ATP}}\right)$ were packed by centrifugation at $1000 \mathrm{~g}$ and $20^{\circ} \mathrm{C}$ for $10 \mathrm{~min}$. Per cent contractility of myofibrils was calculated using the formula: \% contractility $=\left(\mathrm{Pv}_{\mathrm{o}}-\mathrm{Pv}_{\mathrm{ATP}}\right) / \mathrm{Pv}_{\mathrm{o}} \times 100$, where $\mathrm{Pv}_{\mathrm{o}}$ is the packed volume of myofibrils before and $\mathrm{Pv}_{\mathrm{ATP}}$ after adding $1 \mathrm{mM} \mathrm{Mg}^{2+}$-ATP in the presence of 0.001 $\mathrm{mM} \mathrm{CaCl}_{2}$.

\section{Measurement of $\mathrm{Ca}^{2+}$ sensitivity}

Two protocols were used to determine $\mathrm{Ca}^{2+}$ sensitivity of myofibrillar preparations at $\mathrm{pH} 7.0$, as follows.

Protocol-1, measuring $\mathrm{Ca}^{2+}$ sensitivity of myofibrillar contractility: The "per cent value in contraction buffer" $v_{A}$ was obtained according to the protocol outlined above (SAKAmoto \& Arai 1979). Value $v_{A}$ is actually $\mathrm{Pv}_{\mathrm{o}}$ in the presence of $\mathrm{Ca}^{2+}$, while $v_{B}$ is the per cent value in relaxing buffer, that is when $\mathrm{Ca}^{2+}$ was chelated by adding $1.0 \mathrm{mM}$ EGTA. $\mathrm{Ca}^{2+}$-sensitivity of myofibrillar contractility $=v_{A}-v_{B}$ (Table 1).

Protocol-2, measuring $\mathrm{Ca}^{2+}$ sensitivity of $\mathrm{Mg}^{2+}$-ATPase activity: $\mathrm{Mg}^{2+}$-ATPase data were processed according to the formula of LEHMAN and SzENT-GYÖRGYI (1975). $\mathrm{Mg}^{2+}$-ATPase $\mathrm{Ca}^{2+}$-sensitivity $(\%)=\left[1-\mathrm{Mg}^{2+} \mathrm{ATPase}\right.$ in the presence of $1 \mathrm{mM}$ EGTA/ $\mathrm{Mg}^{2+}$ ATPase $] \times 100$ (Table 1).

Table 1. Comparison of $\mathrm{Ca}^{2+}$-sensitivity values of myofibrillar contractility and $\mathrm{Mg}^{2+}$-ATPase activity of Isoparorchis hypselobagri and its host Wallago attu at neutral $\mathrm{pH}(7.0)$

\begin{tabular}{|c|c|c|c|c|}
\hline & \multicolumn{3}{|c|}{ Myofibrils (packed volume estimate)* } & \multirow{2}{*}{$\begin{array}{c}\mathrm{mMg}^{2+}- \\
\text { ATPase** } \\
\begin{array}{c}\text { Ca-sensitivity } \\
(\%)\end{array}\end{array}$} \\
\hline & $\begin{array}{l}\% \text { contractility } \\
\text { (A) }\end{array}$ & $\begin{array}{l}\% \text { relaxation } \\
\text { (B) }\end{array}$ & $\begin{array}{l}\text { Ca-sensitivity } \\
(\%) \quad(\mathrm{A}-\mathrm{B})\end{array}$ & \\
\hline Parasite & 48 & 30 & 18 & 84 \\
\hline Host skeletal muscle & 68 & 58 & 10 & 96 \\
\hline Host swim bladder & 19.3 & 19 & 0.3 & 00 \\
\hline
\end{tabular}

*Calculated on the basis of reduction in packed volume according to Sakamoto and Arai (1979). $\%$ contractility $=\left(\mathrm{Pv}_{\mathrm{o}}-\mathrm{Pv}_{\mathrm{ATP}}\right) / \mathrm{Pv}_{\mathrm{o}} \times 100$, where $\mathrm{Pv}_{\mathrm{o}}$ is the packed volume of myofibrils before and $\mathrm{Pv}_{\mathrm{ATP}}$ after adding $1 \mathrm{mM} \mathrm{Mg}{ }^{2+}$-ATP and $0.001 \mathrm{mM} \mathrm{CaCl}_{2 . .} \mathrm{A}=\%$ contractility in the presence of $0.001 \mathrm{mM} \mathrm{CaCl}_{2} ; \mathrm{B}=\%$ contractility upon chelation of $\mathrm{Ca}^{2+}$ with $1.0 \mathrm{mM}$ EGTA.

$* *$ Calculated according to the formula of Lehman and Szent-Gyorgyi (1975): $\mathrm{Ca}^{2+}$-sensitivity (\%) $=\left[1-\mathrm{Mg}^{2+}\right.$ ATPase in the presence of $1 \mathrm{mM} \mathrm{EGTA} / \mathrm{Mg}^{2+}$ ATPase $] \times 100$. 


\section{RESULTS}

For credible identification of the structural polypeptides, SDS-PAGE profiles of the original NAMs as well as their immunoprecipitates were compared. To raise antiserum, total NAM of white dorsolateral skeletal muscle of the host $W$. attu was used as the antigen. Fig. 1 compares SDS-PAGE profiles of immunoprecipitate of the trematode NAM (lane 3) with immunoprecipitates of the host skeletal muscle NAM (lane 1) and swim bladder NAM (lane 4). Lanes 2 and 5 are normal controls of NAMs of the trematode and the swim bladder, respectively. SDS-PAGE profile of NAM of the host muscle immunoprecipitate shows structural polypeptides typical of striated muscle NAM, namely: myosin heavy chain $(\mathrm{MyHC}=200 \mathrm{kD})$, actin $(45 \mathrm{kD})$, tropomyosin $(36 \mathrm{kD})$, troponins $(26$ and $18 \mathrm{kD})$ and myosin light chains $(\mathrm{LCs}=12-23 \mathrm{kD})$. Importantly, NAM of I. hypselobagri shows a prominent band of $98 \mathrm{kD}$ stacking just below MyHC in the SDS-PAGE profile (Fig. 1, lane 2). However, the SDS-PAGE profile of immunoprecipitate of the trematode NAM lacks the 98-kD band (Fig. 1, lane 3). Since the antigen "host skeletal muscle NAM" lacked invertebrate-specific $98-\mathrm{kD}$ paramyosin, the antiserum raised against this NAM was unlikely to have anti-98 kD-polypeptide antibodies.

The effect of $0.001 \mathrm{mM} \mathrm{Ca}^{2+}$ on the packed volume $\left(\mathrm{Pv}_{\mathrm{o}}\right)$ of the myofibrils at various $\mathrm{pH}$ values is shown in Fig. 2. With the increasing $\mathrm{pH}$, a gradual increase oc-

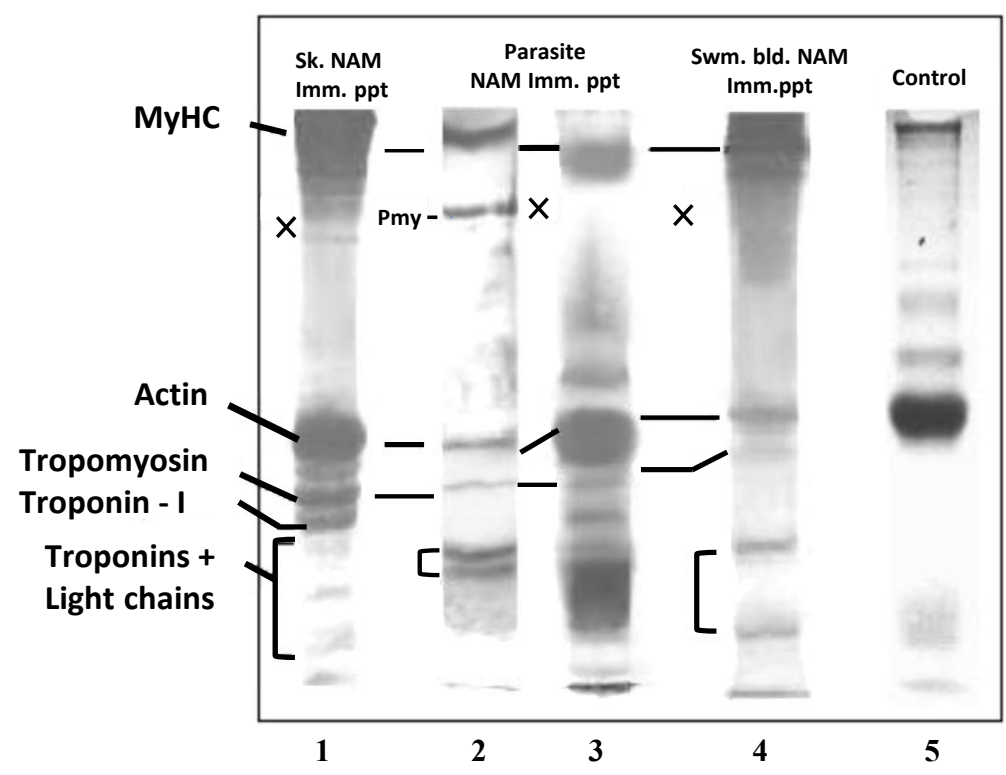

Fig. 1. SDS-PAGE profiles of immunoprecipitated natural actomyosins (NAMs) of the trematode Isoparorchis hypselobagri and the host catfish Wallago attu. Sk = skeletal muscle; imm.ppt = immunoprecipitate; Swm. Bld. = swim bladder; $\mathrm{MyHC}=$ myosin heavy chain Pmy $=$ paramyosin; $\mathrm{x}=$ paramyosin band absent. Molecular weights $\left(M_{r}\right)$ of identified polypeptides: MyHC $200 \mathrm{kD}$; actin $45 \mathrm{kD}$; tropomyosin $36 \mathrm{kD}$; troponins $26 \mathrm{kD}, 18 \mathrm{kD}$; myosin light chains (LCs) $3-12 \mathrm{kD}$ 

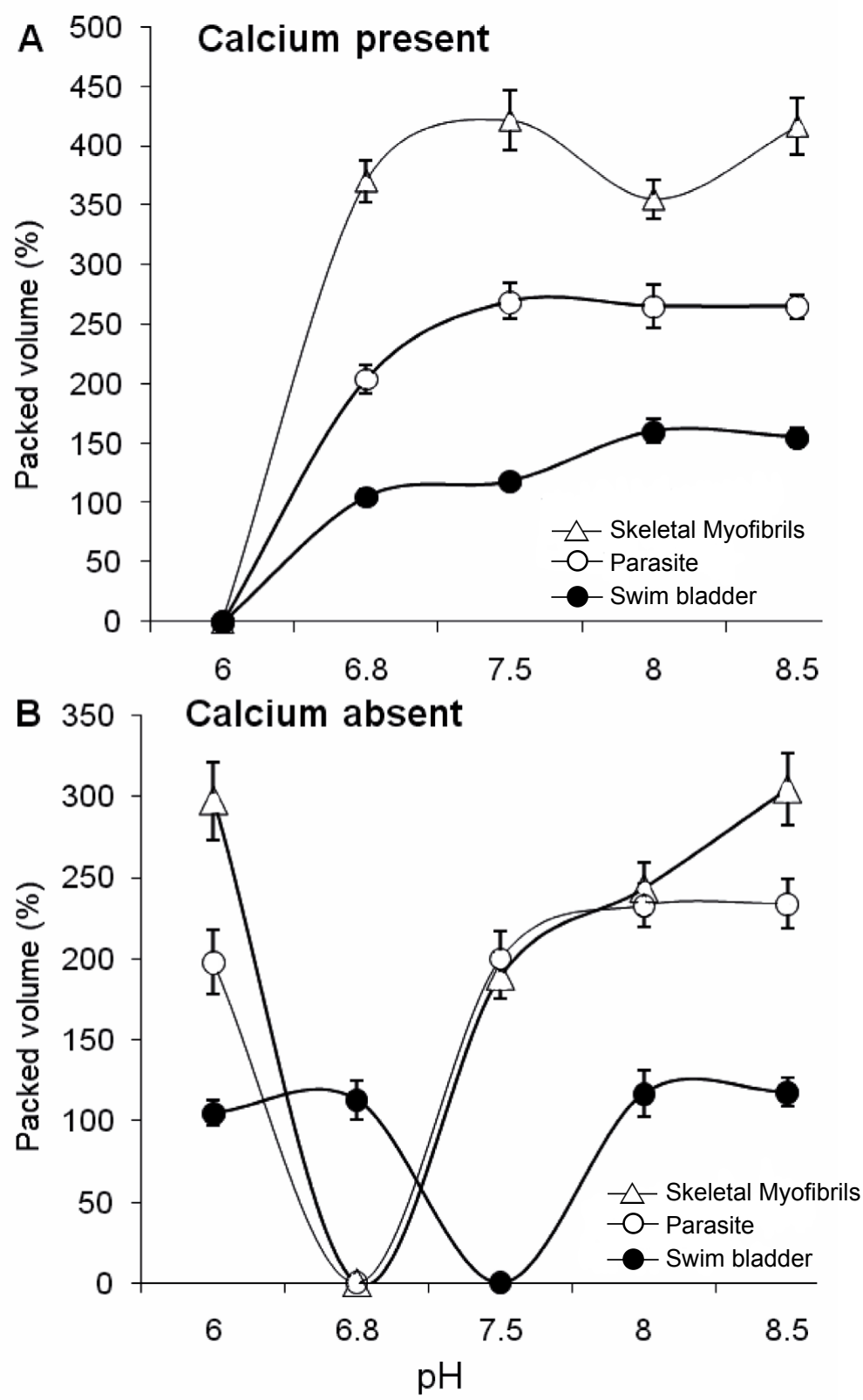

Fig. 2. Effect of calcium on water retention by myofibrils of the trematode Isoparorchis hypselobagri and the host catfish Wallago attu skeletal and swim bladder muscle at various $\mathrm{pH}$ values: (A) increase in packed volume $\left(\mathrm{Pv}_{\mathrm{o}}\right)$ in the presence of $0.001 \mathrm{mM} \mathrm{CaCl}_{2} ;(\mathrm{B})$ changes following chelation of $\mathrm{Ca}^{2+}$ with 1 mM EGTA. Buffers: Tris-maleate ( $\mathrm{pH}$ 6.0-7.1); Tris- $\mathrm{HCl}(\mathrm{pH} 7.5-8.5)$ 

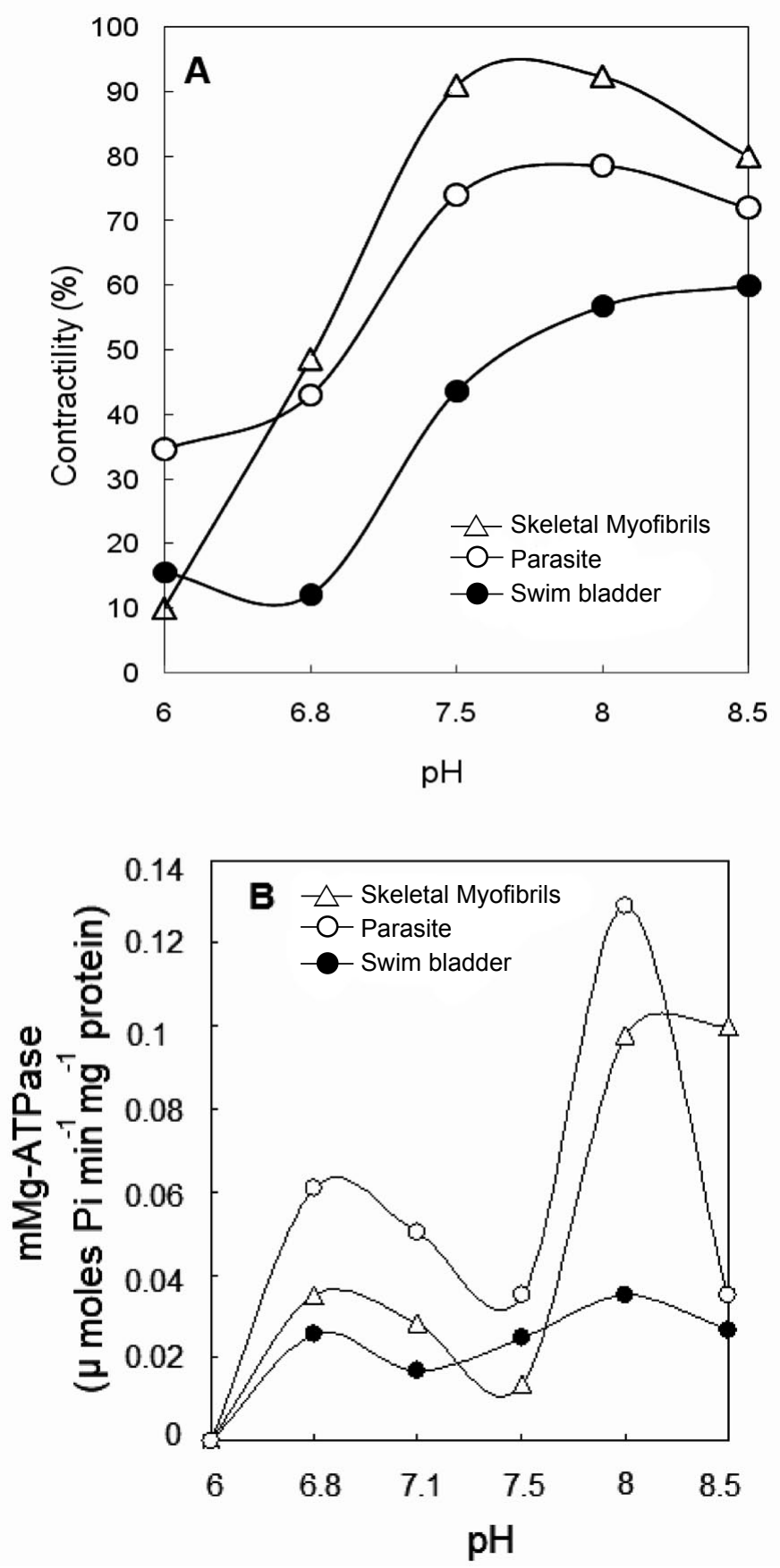

Fig. 3. Myofibrillar contractility (A) and $\mathrm{mMg}^{2+}$-ATPase activity (B) of Isoparorchis hypselobagri as well as its host Wallago attu skeletal and swim bladder muscle at various $\mathrm{pH}$ values. Buffers like in Fig. 2 

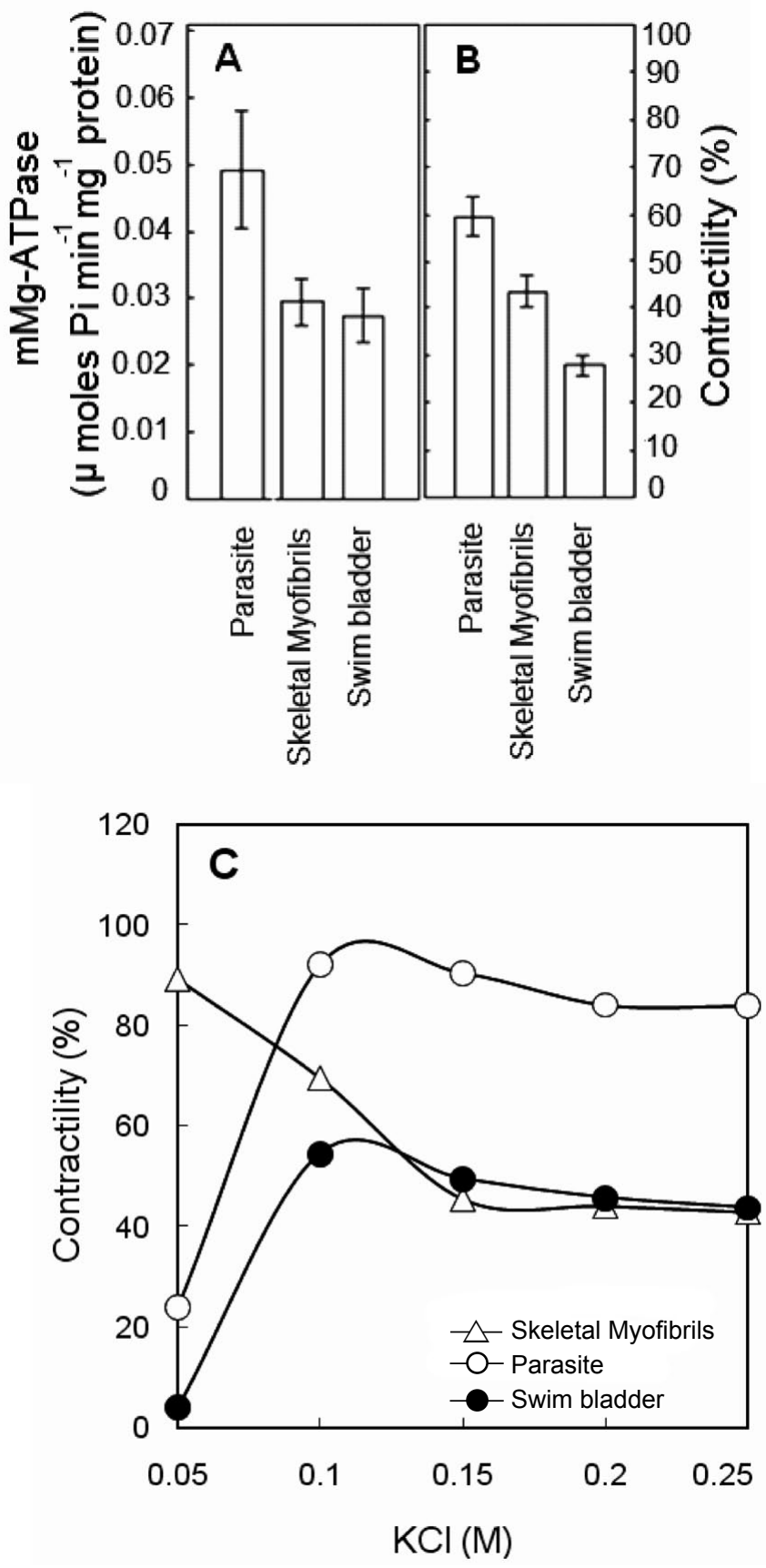

Fig. 4. Relative specific $\mathrm{mMg}^{2+}$-ATPase activity (A) and the per cent contractility of myofibrils; (B) of Isoparorchis hypselobagri as well as its host Wallago attu skeletal and swim bladder muscle at neutral $\mathrm{pH}(7.0)$; (C) contractility of myofibrils from the above sources at various concentrations of $\mathrm{KCl}$ and neutral $\mathrm{pH}(7.0)$ 
curred in the packed volume $\left(\mathrm{Pv}_{\mathrm{o}}\right)$ of myofibrils apparently due to water influx. Muscle-type specific differences were observed in the influx: host muscle myofibrils $>$ trematode myofibrils $>$ swim bladder myofibrils (Fig. 2A). However, when $\mathrm{Ca}^{2+}$ was chelated with EGTA, the trematode and host skeletal muscle myofibrils displayed no volume change at physiological $\mathrm{pH}$ (6.8-7.0), while swim bladder myofibrils required a pH of 7.5 (Fig. 2B).

As explained in Materials and Methods, addition of $\mathrm{Mg}^{2+}-\mathrm{ATP}$ in the presence of $0.001 \mathrm{mM} \mathrm{CaCl}$ brought a reduction in the packed volume of myofibrils, which is taken as contractility in this study (Fig. 3A). Contractility, like myofibrillar $\mathrm{Mg}^{2+}-$ ATPase activity (Fig. 3B), was a pH-dependent function for the trematode, swim bladder, and host muscle myofibrils. Two pH maxima were observed in myofibrillar $\mathrm{Mg}^{2+}$-ATPase $\left(\mathrm{mMg}^{2+}\right.$-ATPase) for each type of myofibrils: one near neutral $\mathrm{pH}$ (6.8) and the other at alkaline $\mathrm{pH}(8.0)$. Around neutral $\mathrm{pH}$, the physiological ATPase $\left(\mathrm{mMg}^{2+}\right.$-ATPase) activity in myofibrils declines in the following order: trematode $>$ host muscle $>$ swim bladder (Fig. 3A). Moreover, at neutral pH, the contractility of swim bladder myofibrils was distinctly lower than the contractility of myofibrils of the host or trematode myofibrils. The trends displayed by $\mathrm{mMg}^{2+}$-ATPase activity and the $\%$ contractility (in the presence of $\mathrm{Mg}$-ATP) of myofibrils from each source were of similar order and magnitude (Fig. 4A-B). Specific $\mathrm{Mg}^{2+}$-ATPase activity of the trematode myofibrils was $\sim 0.06 \mu \mathrm{M} \mathrm{P} i \mathrm{~min}^{-1} \mathrm{mg}^{-1}$ protein, while the swim bladder and host muscle myofibrils had specific activity levels of $\sim 0.03$ and $0.025 \mu \mathrm{M} \mathrm{P} i$ $\mathrm{min}^{-1} \mathrm{mg}^{-1}$ of protein, respectively (Fig. 4A).

The contractility of swim bladder myofibril preparation was least affected by chelating $\mathrm{Ca}^{2+}$ with EGTA, indicating that its contractility is not a troponin-dependent function (Table 1). Correspondence between the trends in $\% \mathrm{Ca}^{2+}$-sensitivity of myofibrillar contractility and the values obtained from $\mathrm{mMg}^{2+}$-ATPase calculated by the established formula of LEHMAN \& SzENT-GYÖRGYI (1975) is displayed in Table 1.

The first order rate constants of inactivation $\left(k_{\mathrm{D}}\right)$ calculated from the slopes of heat inactivation plots of $\mathrm{Ca}^{2+}$-ATPase were: $13.21 \times 10^{-5}$ for the trematode, $10.5 \times 10^{-5}$ for the host swim bladder, and $11.9 \times 10^{-5}$ for the host skeletal myofibrils.

\section{DISCUSSION}

In contrast to many other parasites, I. hypselobagri resides in the aerobic environment of the swim bladder of its definite host, the catfish $W$. attu. Occurrence of its own myoglobin with a distal tyrosine or hemoglobin of high oxygen affinity (RASHID et al. 1997; KIGER et al. 1998) are examples of its adaptation to the oxygenrich environment at the respiratory level (SiddiQui \& Nizami 1975). Since muscle functions require abundant oxygen to replenish ATP via oxidative phosphorylation, muscle stores oxygen as oxymyoglobin in the sarcoplasm. The present data on $I$. hypselobagri for the first time demonstrate that biochemical properties of its myofibrils/NAM are fast-muscle-like and thus consistent with metabolic requirements of an aerobic environment.

Close resemblance of the polypeptide composition of $I$. hypselobagri NAM with the striated muscle and the differences from smooth muscle of the swim bladder 
strongly suggest that striated-muscle-like contractile apparatus dominates the muscle mass of I. hypselobagri (Fig. 1). Polypeptide contents of myosin (MyHC and LCs) suggest that the principal contractile protein of thick filaments of myofibrils in I. hypselobagri is type-II myosin. Importantly, a $98-\mathrm{kD}$ band existed in SDS-PAGE profiles of native NAM of I. hypselobagri. A corresponding band in SDS-PAGE profiles of immunoprecipitate of the trematode NAM was absent, since the antibodies were raised against the catfish skeletal muscle NAM that contained no paramyosin (Fig. 1, lane 3). Being diagnostic of all categories of parasites, including trematodes, the $98-\mathrm{kD}$ polypeptide has to be the paramyosin, which participates in forming myosin thick filaments (Macmanus \& Loukas 2008). Solubility at acid pH confirmed it as paramyosin. Evidently, SDS-PAGE profiles of immunoprecipitates of muscle types of typical polypeptide composition can be used to cross-check reliably the presence or absence of a particular structural polypeptide in parasite muscle extracts. Similarly, SDS-PAGE profile of the immunoprecipitate identify swim bladder NAM as typical of smooth muscle, since it lacks the polypeptides corresponding to $M_{r}$ of the regulatory proteins, troponins, and tropomyosin (Fig. 1, lane 3).

Ion channels are important in controlling the influx of water and ions into muscle fibers and bundles. The trematode and the host skeletal muscle myofibrils showed a similar extent of swelling or water influx due to the presence of calcium on such channels (Fig. 2A). After $\mathrm{Ca}^{2+}$-chelation with EGTA, the volume of the trematode and the host skeletal muscle myofibrils remained unchanged around neutral $\mathrm{pH}$ values (6.8-7.0), indicating no or zero water influx (Fig. 2B). Zero influx-pH value for the swim bladder myofibrils was slightly higher $(\mathrm{pH} \mathrm{7.5),} \mathrm{and} \mathrm{water} \mathrm{influx} \mathrm{was} \mathrm{least}$ affected due to $\mathrm{pH}$ variations and the absence of calcium. These results suggest some similarities between the trematode and host skeletal muscle myofibrils, with particular reference to ion channels and their differences from the swim bladder myofibrils.

Myofibril contractility in this study was assayed on the basis of volume changes after adding $\mathrm{Mg}^{2+}$-ATP and $0.001 \mathrm{mM} \mathrm{CaCl}$. $\mathrm{Mg}^{2+}$-ATPase in the presence of trace calcium was regarded as the physiological ATPase and thus a reflection of functionality (Fig. 3A). Both of these parameters showed a gradual increase, corresponding to increasing alkaline $\mathrm{pH}$, with close resemblance between the trematode and host skeletal muscle myofibrils (Fig. 3A-B). Although myofibril contractility in this study was assayed using a simple protocol (see Materials and Methods), its concordance with $\mathrm{mMg}^{2+}$-ATPase at physiological $\mathrm{pH}$ (Fig. 4) demonstrates its reliability and usefulness as a comparative parameter.

At low salt concentrations used for routine $\mathrm{mMg}^{2+}$-ATPase assays, ATPase activity is an established parameter of "actin-myosin interaction". However, when this interaction was monitored as "myofibrillar contractility", some differences were also observed (Fig. 4C). Up to $0.15 \mathrm{M} \mathrm{KCl}$, the trend of myofibrillar contractility of I. hypselobagri was more similar to that observed in the swim bladder than in the host skeletal muscle myofibrils. This suggests that despite indications that contractility of the trematode myofibril preparation appears to be troponin-mediated, its contractile apparatus differs in some aspect(s) of interactions of myosin with thin filament proteins. The inference is further supported by the fact that the contractility differences observed up to $<0.15 \mathrm{M} \mathrm{KCl}$ disappear as the salt concentration reaches $>0.2 \mathrm{M} \mathrm{KCl}$. 
It is well known that at or above $0.2 \mathrm{M} \mathrm{KCl}$, myosin becomes soluble, thick filaments disrupt, and actin-myosin dissociate. The graph becomes steady because at this concentration the actin-myosin interaction-dependent changes in myofibrils can occur no more.

So as far as the $\mathrm{Ca}^{2+}$-regulation of muscle contraction is concerned, parasites and other invertebrates display more complexity than vertebrates (LEHMAN \& SZENT-GYÖRGYi 1975; HoOPER \& THUMA 2005). They might have either thin-filament-regulation or myosin-light-chain regulation, but generally muscle contraction is controlled by dual regulation (HOOPER et al. 2008). We determined $\mathrm{Ca}^{2+}$-sensitivity using 2 procedures: for contractility and $\mathrm{Mg}^{2+}$-ATPase activity. While $\mathrm{Ca}^{2+}$-sensitivity values of troponin containing myofibrils of the trematode and host skeletal muscle corresponded with the order and magnitude of both "contractility" and "physiological ATPase" (Fig. 3), swim bladder myofibrils did not show $\mathrm{Ca}^{2+}$-sensitivity under our experimental conditions (Table 1). Our data once again support that bulk of the trematode total muscle is fast skeletal-muscle-like. On this basis, the swim bladder muscle is of the smooth type, which is consistent with its polypeptide composition lacking troponins (Fig. 1, lane 4). Since smooth muscle lacks troponins, its contraction has to be myosin-regulated. The overall biochemical profile of swim bladder musculature of $W$. attu is in agreement with published record on other teleosts (APPELT et al. 1991).

Thermostability of enzyme activities is an established inverse measure of the adaptation to the body or ambient temperature (ARAI 2002; WATABE 2002). There is no report on thermal stability of parasite NAM for comparison. The rate constants of myofibrillar $\mathrm{Ca}^{2+}$-ATPase inactivation $\left(k_{\mathrm{D}}\right)$ of the host skeletal muscle, swim bladder, and the trematode were similar $\left(13.21 \times 0^{-5}, 10.5 \times 10^{-5}\right.$, and $\left.11.9 \times 10^{-5}\right)$. Therefore, thermostability kinetics of ATPase of $I$. hypselobagri may represent a case of parasite-host co-evolution.

In conclusion, this study suggests that the bulk of $I$. hypselobagri musculature is fast striated-muscle-like in terms of polypeptide composition, water retention, contractility, ATPase activity, and $\mathrm{Ca}^{2+}$-sensitivity, with myosin type-II as the major contractile protein. Kinetics of $\mathrm{Ca}^{2+}$-ATPase inactivation indicates co-evolution of myofibrillar stability of the trematode and the host. Collectively, these characteristics reflect adaptability to an oxygen-rich environment in the tropical host.

Acknowledgements: We are obliged to the University and the Chairman, Department of Zoology, for providing the facilities; and to Professor of Parasitology, Athar Husain Siddiqui, for reviewing the manuscript. Thanks are due also to Profs. Iqbal Parwez and Syed Mohammad Abbas Abidi for their timely help. Support of Dr. Bushra Ateeq, University of Michigan (USA), in preparing the manuscript is also thankfully acknowledged.

\section{REFERENCES}

Ahmad R., Hasnain A. 2006. Correlation between biochemical properties and adaptive diversity of skeletal muscle myofibrils and myosin of some air-breathing teleosts. Ind. J. Biochem. Biophys. 43: 217-225. 
Appelt D., Shen V., Franzini-Amstrong C. 1991. Quantitation of Ca +ATPase, feet and mitochondria in super fast muscle fibers from the toadfish, Opsanus tau. J. Muscle. Res. Cell. Motil. 12: $543-552$.

ARAI K. 2002. Denaturation of muscular protein from marine animals and its control. Bull. Jap. Soc. Sci. Fish. (Nippon Suisan Gakkai-shi) 68: 137-143.

Chaparro-Olaya J., Margos G., Coles D. J., Dluzewski A. R., Wasserman M. M. Pinder J. C. 2005. Plasmodium falciparum myosins: transcription and translation during asexual parasite development. Cell. Motil. Cytoskel. 60: 2000-2002.

Cruz-Rivera M., Reyes-Torres A., Reynoso-Ducoing O., Flisser A., Ambrosio J. R. 2006. Comparison of biochemical and immunological properties of myosin II in Taeniid parasites. Cell. Biol. Internat. 30: 598-602.

Dobrowolski J. M., Carruthers V. B., Sibley L. D. 1997. Participation of myosin in gliding motility and host cell invasion by Toxoplasma gondii. Mol. Microbiol. 26: 163-173.

Field S. J., Pinder J. C., Clough B., Dluzewski A. R., Wilson R. J. M., Gratzer W. B. 1993. Actin in the merozoite of the malaria parasite, Plasmodium falciparum. Cell Motil. Cytoskel. 25: 43-48.

Gonzalez-Malerva L., Cruz-Rivera M., Reynoso-Ducoing O., Retamal C., Flisser A., AmbroSIo J. R. 2004. Muscular myosin isoforms of Taenia solium (cestoda). Cell. Biol. Int. 28: 885-894.

Gornall G. A., Bardawill C. J., David M. 1949. Determination of Serum proteins by means of the Biuret reagent. J. Biol. Chem. 177: 751-766.

Heintzelman M. B. 2004. Actin and myosin in Gregarina polymorpha. Cell. Motil. Cytoskel. 58: 83-95.

Hooper S. L., Thuma J. B. 2005. Invertebrate muscles: muscle specific genes and proteins. Physiol. Rev. 85: 1001-1060.

Hooper S. L., Hobbs K. H., Thuma J. B. 2008. Invertebrate muscles: Thin and thick filament structure; molecular basis of contraction and its regulation, catch and asynchronous muscle. Prog. Nerobiol. 86: 72-127.

Katta S. S., Sahasrabuddhe A. A., Gupta C. M. 2009. Flagellar localization of a novel isoform of myosin, myosin XXI in Leishmania. Mol. Biochem. Parsaitol. 164: 105-110.

Kiger L., Rashid K. A., Griffon N., Haque M., Moens L., Gibson O. H., Poyart C., Marden M. C. 1998. Trematode haemoglobin show exceptionally high oxygen affinity. Biophys. J. 75: 990-998.

Lehman W., Szent-Gyorgyi A. G. 1975. Regulation of muscular contraction: distribution of actincontrol and myosin-control in the animal kingdom. J. Gen. Physiol. 66: 1-30.

Macmanus D. P., Loukas A. 2008. Clinical Status of Vaccines for Schistosomiasis. Clin. Microbiol. Rev. 21: 225-242.

OAKLeY B. R., KIRSCh D. R., Moriss N. R. 1980. A simplified ultrasensitive silver stain for detecting proteins in polyacrylamide gels. Anal. Biochem. 105: 361-363.

Pezzela-D’Alessandro N., Lemoal H., Bomhomme A., Valere A., Klein C. Gomez-Martin J., PINON J. M. 2001. Calmodulin distribution and the actomyosin cytoskeleton in Toxoplasma gondii. J. Histochem. Cytochem. 49: 445-454.

Pinder J. C., Fowler R. E., Dluzewsis A. R., Bannister L. H., Lavin F. M., Mitchell G. H., Wilson R. J. M., Gratzer W. B. 1998. Actomyosin motor in the merozoite of the malaria parasite, Plasmodium falciparum: implications for red cell invasion. J. Cell. Sci. 111: 1831-1839.

Rashid K. A., Hauwaert M. L., Haque M., Siddiqi A. H., Lasters I., Demaeyer M., Griffon N., Marden M. C., Dewilde S., Clauwaert J., Vinogradov S. N., Moens L. 1997. Trematode myoglobins, functional molecules with a distal tyrosine. J. Biol. Chem. 272: 2992-2999.

SaKamoto M., Arai K. 1979. A fundamental study on relationship between ATPase activity and contractile property of fish myofibrils. Bull. Jap. Soc. Sci. Fish. (Nippon Suisan Gakkai-shi) 45: $1575-1583$. 
Schmitz S., Schaap I. A., Kleinjung J., Harder S., Grainger M., Calder M., Calder L., Roswnthal P. B., Holder A. A., Veiger C. 2010. Malarial parasite actin polymerization and filament structure. J. Biol. Chem. 285: 36577-36585.

SchÜLer H., Matuschewski K. 2006. Regulation of apicomplexan microfilament dynamics by a minimal set of actin-binding proteins. Traffic 7: 1433-1439.

SiddiQui A. H., Nizami W. A. 1975. Gas content of swim bladder of Wallago attu and oxygen consumption in Isoparorchis hypselobagri (Trematoda). Z. Parasitenkd. 47: 263-268.

Soldatti-Favre D. 2008. Molecular dissection of host cell invasion by the apicomplexans: the glideosomes. Parasite 15: 197-205.

WataBe S. 2002. Temperature plasticity of contractile proteins in fish muscle. J. Exp. Biol. 205: 2231-2236.

Wetzel D. M., Hakansson S., Hu K., Roos D., Sibley L. D. 2003. Actin filament polymerization regulates gliding motility by apicomplexan parasites. Mol. Biol. Cell. 14: 396-406. 